\title{
CORPORATE LIABILITY OF ENERGY/NATURAL RESOURCES COMPANIES AT NATIONAL LAW FOR BREACH OF INTERNATIONAL HUMAN RIGHTS NORMS
}

\author{
Olivier Salas-Fouksmann*
}

\begin{abstract}
This paper examines the challenges posed by domestic judicial mechanisms to address the liability of natural resources companies for human rights abuses and environmentally harmful activities, through the foreign operations of their subsidiaries. It explores the conceptual difficulties underlying the notion of liability at national law for violating international norms and it highlights current challenges raised by the arguments made before the United States Supreme Court in the Kiobel case to stop victims of human rights violations from bringing claims under the Alien Tort Statute for corporate abuses committed in the territory of a foreign state. The paper raises the concern that corporate impunity for violation of human rights norms might become justified at national law by the difficulty to find sources of international law to hold corporations liable for violation of international norms. It finally sheds light on enforcement challenges for establishing private rights of action and determining liability of corporate actors, arguing that the reluctance of national courts to expand principles of corporate liability and extraterritorial jurisdiction for corporate harms might affect long-term reforms to hold natural resources companies liable for their abuse of international human rights norms.
\end{abstract}

\section{A. INTRODUCTION}

The primary function of human rights norms, as envisaged in the post war period, was to protect individuals against abuse by their own, or sometimes by other, state entities. That said, it has become clear that many important threats to the rights of individuals come not only from states but also from non-state actors, including international corporations.

While there are established rules to invoke the liability of states for their breach of international law obligations ${ }^{1}$, there is no equivalent to hold corporations liable for violating human rights norms. Despite arguments ${ }^{2}$ that support direct liability of corporations in areas such as international criminal law, the lack of obvious international remedies for human rights abuse committed by corporations, means that corporate activities remain largely governed by national law, as are the mechanisms to hold them

\footnotetext{
* Solicitor in England and Wales, LL.M (University College London) 2012

${ }^{1}$ ILC Draft Articles on Responsibility of States for Internationally Wrongful Acts, 2001, 'Report of the International Law Commission on the Work of its $53^{\text {rd }}$ session (23 April-1 June and 2 July 2001-10 August 2001) UN Doc A/56/10.

${ }^{2}$ Andrew Clapham, 'Extending International Criminal Law beyond the Individual to Corporations and Armed Opposition Groups' (2008) 6 J Intl Criminal Justice 899, 925926.
} 
accountable. The lack of specific fora to bring human rights claims against corporations also means that liability for breach of international human rights norms is essentially a matter for national courts to deal with.

The scale of investments by natural resources companies ('NRCs'), primarily in developing countries, combined with their role in generating revenues for host States, is significant of their economic and political influence ${ }^{3}$. Collusion with host governments has resulted in allegations of corporate complicity in governmental violations of basic human rights. At the same time, impact on the environment and communities surrounding their operations have made NRCs particularly prone to lawsuits as the principal perpetrator of human rights abuses.

This paper evaluates the challenges posed to domestic judicial mechanisms to address corporate liability of NRCs for their alleged violation of international human rights norms.

Part B considers some conceptual difficulties underpinning the notion of corporate liability for breach of human rights norms.

Part $\mathrm{C}$ explores the arguments in the current Kiobel ${ }^{4}$ case before the US Supreme Court ${ }^{5}$ to illustrate the legal debate underpinning the question of corporate liability at national law for violation of human rights norms. Kiobel is a case arising from claims under the Alien Tort Statute ('ATS') that Royal Dutch Petroleum ('Shell') was complicit with the Nigerian government in human rights abuse, including torture, extra-judicial killings and crimes against humanity against the Ogoni people, who were opposing oil exploration in their territory during the 1990s. By the time of publication, the US Supreme Court will have determined whether the ATS, which allows lawsuits in the US for violation of international law, also creates a legal basis for suits against corporations.

Part D considers the challenges to enforcement against corporations, at national level, of breaches of human rights norms. In addition, consideration is given to policy options to facilitate coordinated approach, drawing on the example of corporate criminal liability.

\footnotetext{
${ }^{3}$ Chris Jochnick, 'Confronting the Impunity of Non-State Actors: New Fields for the Promotion of Human Rights' (1999) 21 Hum. Rts. Q. 56, 58 (“Texaco operated for years in the Amazon as [...] a state unto itself, with annual earnings four times the size of Ecuador's GNP"').

${ }^{4}$ Kiobel v Royal Dutch Shell Petroleum Co. 621F.3d.11 (2d Cir. Sept. 17, 2010).

${ }^{5}$ Transcript of Oral Arguments, US Supreme Court, February 28, 2012, available at http://www.supremecourt.gov/oral arguments/argument transcripts/10-1491.pdf.

${ }^{6} 28$ US Code $\& 1350$.
} 


\section{B. The Conceptual Difficulties UnderPinNing the Notion OF CORPORATE LIABILITY FOR BREACH OF HUMAN RightS NORMS}

\section{CATEGorization of Human RightS AbusEs Committed by NRCS}

This section suggests that, while it is possible to identify a consistent pattern of 'human rights-type abuses' committed by NRCs, there are conceptual difficulties in holding corporations liable for violating international human rights norms.

Despite longstanding and unresolved debate about whether corporations could be the 'subjects' of international law and which specific rights pertain to business activities, the fact that corporations have become participants in the international legal system with the capacity to bear both rights and duties has reached international consensus. However, whilst corporations may have, in theory, the ability to impact the full range of human rights, some norms appear to be at a greater risk in the operating context of NRCs, such as the right to life or fair trial (in cases where vested interests with the host government expose NRCs to increased risks of aiding and abetting local police or armed forces in containing resistance to their operations), or the right to a sound environment or collective rights to determine how natural resources should be protected.

Tar sands activities in Canada have been described as one of the world's biggest environmental disaster, turning vast carbon sinks into the largest emitters of carbon dioxide on the planet. ${ }^{7}$ New exploration methods addressing increased global oil demand (including gas shale exploitation in the US or the granting of hydraulic fracturing licenses in the UK), together with the building of processing facilities and pipelines associated with oil development mean that oil companies are possibly more prone to negatively impacting the environment and disrupting communities surrounding their operations. The granting of exploration licenses and the negotiation of Production Sharing Agreements (PSAs) with host States may also result in difficult issues of consent in relation to land access and resettlement of local stakeholders. Indigenous peoples do not always welcome the investment of oil multinationals. This is despite the potential of these investments to bring

7 Steven Weissman, The Berkeley Blog (24 June 2010), available at http://blogs.berkeley.edu/2010/06/24/alberta\%E2\%80\%99s-tar-sands-a-slow-motionequivalent-of-the-gulf-disaster/. 
economic and social opportunities. Local communities may perceive these developments as incompatible with their aspirations and traditional values. ${ }^{8}$

The magnitude of revenues that oil projects constitute for host States also means that legal arrangements between oil corporations and host governments are often based on compromise. In the Baku-Tbilisi-Ceyhan (BTC) Pipeline project, the freezing effect of the 'non-interference' provision in the Host Government Agreement (HGA) ${ }^{9}$ between the BP consortium and the Turkish Government prevents Turkey from intervening in key areas of the project, including land rights and environment, except in extreme circumstances. The high threshold for State intervention set in the HGA might conflict with the state duty to protect fundamental human rights. ${ }^{10}$ It is also frequent for contractual arrangements with host states to transfer responsibility for maintaining security issues to corporations. In certain circumstances, this has meant that the containment of protest by security forces has resulted in host states being accused of violating human rights norms, including unlawful detention and torture. In such instances, corporations have been sued for complicity with state organs.

\section{National enforcement of Human Rights norms and Policy INCOHERENCE}

With the exception of US legislation, which provides for a civil cause of action directly associated with the violation of human rights norms under the ATS, no other legislation allows victims to obtain redress directly for violations of human rights per se. The 'human rights litigation' label is somewhat misleading, since far from dealing with violation of international norms as reflected in custom and treaties, cases against NRCs are typically concerned with providing civil remedies to the victims, whose main concern is to obtain compensation from defendant corporations for physical injury and property damage caused by negligence or foresight. ${ }^{11}$ However, domestic laws governing corporate activities (e.g. corporate, investment law)

\footnotetext{
${ }^{8}$ Deanna Kemp and others, 'Just relations and company-community conflict in mining' (2011) 101 Journal of Business Ethics 93.

${ }^{9}$ HGA, Article 5 ("Government Guarantees").

${ }^{10}$ Catherine Redgwell, 'Contractual and Treaty Arrangements Supporting Large European. Transboundary Projects: Can adequate Human Rights and Environmental Protection be secured?' in Energy Networks and the Law: Innovative Solutions in Changing Markets (OUP 2012) 106-108.

${ }^{11}$ Richard Meeran, 'Tort litigation against multinationals for violation of human rights: an overview of the position outside the US' (2001) Vol 3:1 City University of Hong Kong Law Review 1.
} 
and their liability, essentially civil and criminal law, do not necessarily pursue the protection of human rights norms. Host states might be tied to Bilateral Investment Treaties ('BITs') offering investors guarantees of fairness and equitable treatment with little regard to their duty to protect human rights. Similar concerns have been raised about the lack of alignment ${ }^{12}$ between government agencies promoting foreign investment and other departments in charge of implementing human rights obligations. What has generally been termed as "horizontal incoherence" 13 creates difficulties in holding corporations liable under national law for their violation of international norms.

\section{Are Corporations the Primary bearers in relation to Human} RIGHTS NORMS?

The question as to whether human rights obligations are only owed by State entities remains a controversial and developing field. The UN Norms on the Responsibilities of Transnational Corporations and Other Business Enterprises with regard to Human Rights ${ }^{14}$ ('the Norms') go beyond the classical view that the primary duty to ensure that corporations respect human rights lies with states. Other instruments such as voluntary initiatives like the UN Global Compact ${ }^{15}$ or soft law instruments like the OECD Guidelines ${ }^{16}$ seek to engage corporations in observing minimum standards of protection in certain fields, including human rights and environmental protection. However, none of these instruments have succeeded in creating generally applicable international law obligations.

The premise of the Norms, i.e. that corporations have greater power than states to affect the realization of human rights and should bear direct responsibility for the rights they impact, was probably going too far in shifting the burden of responsibility from sovereign states to private entities.

\footnotetext{
${ }^{12}$ UNHRC, Eighth Session 'Report of the Special Representative of the SecretaryGeneral on the issue of human rights and transnational corporations and other business enterprises, John Ruggie, Protect, Respect and Remedy: a Framework for Business and Human Rights' (7 April 2008) UN Doc A/HRC/8/5, paras 39-41.

${ }^{13}$ Horizontal incoherence generally occurs when certain government bodies, often in the context of host States concerned of attracting foreign investment, work at cross-purposes with State's human rights obligations and those in charge of implementing them. See (n 12), paras 33-38.

${ }^{14}$ UN Sub-Commission on the Promotion and Protection of Human Rights, $22^{\text {nd }}$ Meeting 13 August 2003 UN Doc. E/CN.4/Sub.2/2003/12.

${ }^{15}$ See United Nations, 'Global Compact', available at www.unglobalcompact.org.

16 OECD, 'Guidelines for Multinational Enterprises' (2011 edition) available at http://www.oecd.org/daf/inv/mne/48004323.pdf.
} 
The challenges faced by the Norms in imposing international law obligations on corporations have also re-emphasised the conceptual difficulty of positioning corporations in the web of international obligations, despite the cross-border nature of multinational companies' operations.

The main argument against imposing international human rights obligations on corporations is that juridical entities should not be allowed to take over the role of states to protect human rights. Where state authority is weak, it is feared that a transfer of duties to corporations to protect human rights may further erode political impetus to fulfil state obligations ${ }^{17}$. This approach has been formulated in the United Nations Guiding Principles on Business and Human Rights ${ }^{18}$ (the 'Guiding Principles') to implement the "Protect, Respect and Remedies" Framework ${ }^{19}$ first introduced in 2008 by the UN Special Representative for Business and Human Rights, Professor John Ruggie (the 'SRSG'). The Guiding Principles distinguish between the "state duty to protect" against third party abuse and the "responsibility of companies to respect human rights". They possibly constitute the most authoritative international statement to date regarding corporate responsibilities, although controversy remains as to whether corporations could not, as a matter of principle, have direct obligations under international law, despite the lack of obvious remedies to hold them accountable. ${ }^{20}$

\section{THE UNCERTAIN SCOPE OF THE UNDERLYING NORMS}

Environmental degradation constitutes a central allegation in cases against energy companies. For instance, in the Shell Oruma case ${ }^{21}$, residents in the Niger delta filed civil suits in The Hague against Shell's Netherlands-based parent, Royal Dutch Shell Plc, and its Nigerian subsidiary, SPDC, in relation to oil pollution associated to SPDC operations. Moreover, in the Trafigura

\footnotetext{
${ }^{17}$ Philip Alston, "The "Not-a-Cat" Syndrome: Can the International Human Rights Regime Accommodate Non-State Actors?' in Philip Alston (ed), Non-State Actors and Human Rights (OUP 2005) 3.

${ }^{18}$ UNHRC, Seventeenth Session 'Report of the Special Representative of the SecretaryGeneral on the issue of human rights and transnational corporations and other business enterprises, John Ruggie, Guiding Principles on Business and Human Rights: Implementing the United Nations "Protect, Respect and Remedy" Framework' (21 March 2011) UN Doc A/HRC/17/31 endorsed at the UN Human Rights Council 11th Session (16 June 2011).

${ }^{19}$ UNHRC (n 12).

${ }^{20}$ Andrew Clapham, Human Rights Obligations of Non-State Actors (OUP 2006) 195252.

${ }^{21}$ Court of The Hague, Judgment in motion contesting jurisdiction of 30 December 2009, Case No 330891/HA ZA 09-579.
} 
case $^{22}$, Ivory Coast citizens brought suits against Trafigura, one of the world's largest oil trading companies, concerning the disposal of hazardous waste in Abidjan. Lawsuits were filed in the Netherlands against the parent company, Trafigura Beheer. Claims were also filed in the UK against the British subsidiary responsible for the company's operations, as well as in the Ivory Coast, where claims based in tort were filed ${ }^{23}$. In Carijano $^{24}$, members of the Peruvian Achuar indigenous group revived a tort claim against Occidental Petroleum for land contamination and adverse health effects resulting from Occidental's operations in the Amazon forest.

The way the abovementioned cases approach environmental rights is essentially anthropocentric: environmental rights are seen as merely deriving from the 'greening' of existing human rights of the so-called first generation, such as the right to life and the right to property ${ }^{25}$, while the focus in establishing corporate liability is primarily on the harmful impact on individual humans, rather than the impact on the environment itself. Whether domestic law is able to transcend this anthropocentric approach to corporate liability in favour of a more eco-centric one might well depend on the ability of international law to formulate and recognize a right to a 'decent' or 'satisfactory environment'. So far, despite the reference at regional level to a "general satisfactory environment" ${ }^{26}$ and the decision in the Onigoland $\operatorname{case}^{27}$ to place substantive environmental obligations on states, the legal foundations of such a right in an instrument of worldwide applicability remain questionable. ${ }^{28}$

The difficulty to achieve a normative status extends, in fact, to the vast majority of 'collective' or third generation rights ${ }^{29}$. The reluctance to accept them as real rights is often justified by their broad formulation as objectives that the international community is seeking to pursue, or mere

\footnotetext{
${ }^{22}$ Yao Essaie Motto \& Others v (1) Trafigura Limited \& (2) Trafigura Beheer BV [2011] EWCA Civ 1150.

${ }^{23}$ Yao Essaie Motto and Ors v Trafigura Ltd \& Trafigura Beheer [2009] High Court, Case No HQ06XO3370/42.

${ }^{24}$ Carijano v Occidental Petroleum Co, $\left(9^{\text {th }}\right.$ Cir. March 3, 2010), No. 08-56187.

${ }^{25}$ Alan Boyle, 'Human Rights or Environmental Rights? A Reassessment' (2007) 18 Fordham Envtl. L. Rev. 471.

${ }^{26}$ African Charter on Human and Peoples' Rights (adopted 27 June 1981, entered into force 21 October 1986), (1982) 21 ILM 58, Article 24.

${ }^{27}$ The Social and Economic Rights Action Center and the Center for Economic and Social Rights v Nigeria, African Commission on Human and Peoples' Rights, Comm.No. 155/96 (2001).

${ }^{28}$ Boyle (n 25) 504-511.

${ }^{29}$ Christian Tomuschat, Human Rights: Between Idealism and Realism (OUP 2003) 5460 .
} 
principles already enunciated in the UN Charter (e.g. peace and security, right to development).

Another example of the normative uncertainty of the rights likely to be affected by NRC operations can be illustrated by the debate of recent years regarding the rights of indigenous peoples. The United Nations Declaration on the Rights of Indigenous Peoples ('UNDRIP') ${ }^{30}$ recognizes that indigenous peoples have a right "to determine and develop strategies for exercising their right to development". ${ }^{31}$ Their right to a healthy environment is set out in Article 29, which refers to "[...] the protection of the environment and the productive capacity of [peoples'] lands [...] and resources". The Declaration is not binding international law. It also took until 2010 for the USA, Canada, Australia and New Zealand to announce their support of the Declaration. At the same time, there are strong arguments to support its normative status. Indigenous rights to participate in resource development are strongly rooted in the International Covenant on Civil and Political Rights (herein 'ICCPR') ${ }^{32}$ and, in particular, in the right to self-determination. ${ }^{33}$ In a case where the granting of mining licenses had resulted in indigenous communities being dispossessed of their land, the South African Constitutional Court found that the 'right to land' was a right of "communal ownership under indigenous law". ${ }^{34}$ Such interpretation of indigenous rights by domestic courts also means that, although the primary responsibility to gain community consent under UNDRIP is on governments, the failure of NRCs to comply with indigenous consultation rights might expose NRCs to increased litigation.

\section{The Challenges posed to Corporate Liability for Violation of International Human Rights Norms in the Review of Kiobel BEFORE THE US SUPREME COURT}

\section{NRCS LIABILITY UNDER THE ATS}

The ATS grants US federal courts jurisdiction for "any civil action by an alien for a tort only, committed in violation of the law of the nations or a

\footnotetext{
${ }^{30}$ UNGA Res 61/295 (13 September 2007).

${ }^{31}$ African Charter (n 26) Art 23.

${ }^{32}$ International Covenant on Civil and Political Rights (adopted 16 December 1966, entered into force 23 March 1976) 999 UNTS 171 (ICCPR) Articles 26/27.

${ }^{33}$ ICCPR Art 1(2); James Anaya, Indigenous People in International Law (OUP 1996) 75-77.

${ }^{34}$ Alexkor Ltd $v$ The Richtersveld Community [2003] AUIndigLawRpr 41; (2003) 8(3)

Australian Indigenous Law Reporter 55, 2-3.
} 
treaty of the United Sates" ${ }^{35}$ Its primary function is to provide civil liability for noxious conduct in violation of international law.

So far, the vast majority of cases against NRCs for alleged violation of human rights norms have been brought in US courts under the ATS. ${ }^{36}$ This is not surprising, given the jurisdictional advantages offered by the broad wording of the statute itself, the large number of NRCs incorporated or headquartered in the US and the fact that civil law jurisdictions generally do not provide for class actions. ${ }^{37}$

In the $U_{n o c a l}{ }^{38}$ case, Burmese nationals alleged that Unocal aided and abetted the Myanmar military in subjecting them to forced labour, murder, rape and torture, in relation with the construction of the Yadana pipeline. In the Presbyterian Church of Sudan case, Talisman Energy, the multinational oil company headquartered in Calgary, Canada, was sued for aiding and abetting genocide in Sudan. ${ }^{39}$ Complicity with state authorities was also the focal point in Bowoto $^{40}$, a case where Chevron's subsidiary in Nigeria was accused of being complicit in human rights abuses when security forces contracted by Chevron fired at staff protesting against Chevron's drilling activities at an offshore platform.

A remarkable feature of ATS litigation against NRCs is that corporations are sued as 'secondary' perpetrators of international crime. Most cases concern situations where corporations are accused of complicity in governmental violations of international law. Despite the Second Circuit Court of Appeal's observations in Unocal ${ }^{41}$ that certain crimes "do not require State action when they are committed in furtherance of other crimes such as [...] genocide or war crimes for ATS liability to attach", state intervention has been a consistent feature of ATS jurisprudence.

The requirement of state intervention raises the issue as to whether US courts regard the ATS as an instrument to promote corporate accountability for human rights abuses or, rather, to pursue US foreign objectives in democratic terms. In the Bhopal litigation, where Union Carbide, the New York-based parent of the Indian subsidiary involved in the environmental

\footnotetext{
${ }^{35}$ US Code (n 6).

${ }^{36}$ Sarah Joseph, Corporations and Transnational Human Rights Litigation (OUP 2004), 146-154.

${ }^{37}$ Meeran (n 11) 15.

${ }^{38}$ John Doe I v UNOCAL Corp, 395F. 3d 932 ( $9^{\text {th }}$ Cir. Sept. 18, 2002), para 3.

${ }^{39}$ Presbyterian Church of Sudan v Talisman Energy, Inc, No. 07-0016 (2 ${ }^{\text {nd }}$ Cir. Oct. 2 , 2009).

${ }^{40}$ Larry Bowoto et al $v$ Chevron Texaco Corp, No. 09-15641 ( $9^{\text {th }}$ Cir. Sep.17, 2010).

${ }^{41}$ John Doe (n 38) para 3.
} 
tragedy, was the 'primary' perpetrator of the alleged offences, the courts refused to adjudicate the case. ${ }^{42}$ Arguably, accepting jurisdiction would have suggested that the Indian legal system was inappropriate to deal with the dispute, which would have caused a political storm, given that India has one of the world's largest democracies. On the other hand, US courts have been happy to become involved with complicity allegations in Sudan, Nigeria or Burma.

\section{BACKGROUND OF THE KIOBEL CASE}

In a controversial opinion, the Second Circuit Court of Appeals in Kiobel concluded by majority (the 'Kiobel majority') that corporations could not be sued under the ATS for violation of international law, since no corporation had "ever been subject to any form of liability (whether civil or criminal) under customary international law". ${ }^{43}$ The fact that liability under international law was limited to natural, as opposed to juridical, persons led the court to conclude that "imposing liability on corporations for violation of customary international law [had] not attained a discernible, much less universal, acceptance among nations". ${ }^{44}$ Accordingly, the plaintiffs' claim was dismissed for lack of subject matter jurisdiction.

The Supreme Court decision, to hear the plaintiffs' appeal on 17 October 2011 is likely to have a major effect on the future of US litigation against corporations for extraterritorial human rights impacts and, more generally, on the notion of corporate liability for human rights abuses. The central question put to the Supreme Court in the plaintiffs' petition was "whether corporations are immune from tort liability for violations of the law of the nations [...] or if corporations may be sued in the same manner as any other private party under the ATS" ${ }^{45}$ However, the controversy on corporate liability refocused on the issue of extraterritoriality following the hearing of 28 February 2012, when the Court asked the parties to submit supplemental briefs for a second hearing on "whether the ATS allows court to recognize a cause of action for violation of international law within the territory of a sovereign other than the US". ${ }^{46}$

\footnotetext{
${ }^{42}$ Union Carbide Corp Gas Plant Disaster at Bhopal, India in Dec, 1984, 634 F. Supp. 842 (Southern District of New York Court May 12,1986).

${ }^{43}$ Kiobel (n 4) 2.

${ }^{44}$ Ibid, Judge Cabranes, 43.

${ }^{45}$ Petition for writ of certiorari, 6 June 2011, 2.

${ }^{46}$ Order of 5 March 2012.
} 
While the focus on corporate complicity has so far maintained a compromise in ATS litigation against NRCs between motives of enhanced corporate accountability and wider policy issues, Kiobel is unprecedented in the way it reopens the debate on the legal basis of corporate liability claims for breach of international norms. This section aims to explore the key arguments in the Kiobel controversy.

\section{KEY ARGUMENTS REVIEW}

(a) Whether corporate responsibility for breach of international norms is a domestic or international law notion

Kiobel turns on two different visions of what determines corporate responsibility for breach of international standards. For the respondents, Shell in this case, the question of 'who' may be liable under the ATS is a question of international law ${ }^{47}$, leaving to individual nations the power to decide 'whether' and 'how' to respond to a violation of international norms. By contrast, the petitioners point to the broader power of states to enact norms of responsibility as a matter of domestic law. ${ }^{48}$ The question of 'who' may be liable becomes essentially a question of domestic enforcement or remedy. The court was clearly split on the issue, with Justice Kagan asserting that "the question of who can be sued is a remedial question"49 and Chief Justice Roberts observing that "under international law, it is critically pertinent to [determine] who is undertaking the conduct that is alleged to violate international norms [...] Governmental torture violates international norms. Private conduct does not." 50

(b) Whether international law recognises a norm of corporate responsibility for breach of human rights norms alleged

(i) The test in Sosa ${ }^{51}$ and its interpretation by the Kiobel majority.

To address the question whether or not international law recognizes a norm of corporate responsibility for breach of human rights norms alleged, the Kiobel majority took a 'norm by norm' approach, considering each violation of human rights alleged in the case, relying on the narrow test established in

\footnotetext{
${ }^{47}$ Brief For Respondents, 27 January 2012, 18.

${ }^{48}$ Brief For Petitioners, 14 December 2011, 12-17.

${ }^{49}$ Oral Arguments (n 5) 37.

${ }^{50}$ Ibid (n 5) 21.

${ }^{51}$ Sosa v Alvarez-Machain, 542 U.S. 692 ( $9^{\text {th }}$ Cir. June 29, 2004).
} 
Sosa, where the Supreme Court constrained the type of violation of international law that could trigger the ATS jurisdiction.

Interpreting the ATS from an historical perspective and relying on the narrow ambit of the "violations of the law of the nation" that qualified when the statute was enacted in 1789, namely piracy and infringement of the rights of ambassadors, the court in Sosa formulated a twofold test, that some have characterized as setting a "very high bar for new causes of action to surmount". ${ }^{52}$ Firstly, the court observed that "federal courts should not recognize private claims under federal law for violations of any international law with less definite content and acceptance among civilized nations than the historical paradigms familiar when the ATS was enacted" ${ }^{53}$ Secondly, the court provided guidance to determine whether a norm is sufficiently definite to support a cause of action stating, at footnote 20 of the opinion, that such determination requires a "related consideration of whether international law extends the scope of liability of a given norm to the perpetrator being sued if the perpetrator is a private actor such as a corporation or an individual". 54

The Kiobel majority and subsequent briefs in support of the respondents rely on this "related consideration", first to justify the broad principle that corporate liability under the ATS derives from international law, then to assess whether customary international law has recognised liability for corporation for the alleged violation of the specific norms in question.

The approach of the Kiobel majority is remarkable from various perspectives: firstly, the justification of such a decisive principle is focused on a footnote of a prior Supreme Court opinion that dealt with the liability of natural as opposed to juridical persons. More importantly, the judiciary showed its determination to make a pronouncement on an ongoing and unresolved legal debate about which human rights norms apply to corporations and on what basis. In assessing whether torture or genocide by private actors violate international law, the Kiobel majority took the "related consideration" in Sosa a step further, by no longer distinguishing perpetrators between state and non-state actors but, instead, between corporations and natural persons, concluding that no sufficient consensus

\footnotetext{
${ }^{52}$ David Scheffer and Caroline Kaeb, 'The Five Levels of CSR Compliance: the Resiliency of Corporate Liability under the ATS and the Case for a Counter Attack Strategy in Compliance Theory' (2011) 29 Berkeley J. Int'1 L. 334, 341.

${ }^{53}$ Sosa (n 51), Justice Souter, 38.

${ }^{54}$ Ibid, footnote 20,38 .
} 
exists in international law that the alleged offenses (i.e. torture and genocide) can be committed directly by corporations. ${ }^{55}$

\section{(ii) The sources considered by the respondents in applying the Sosa test.}

Various sources are used to assess whether corporate liability for violation of international human rights has reached the status of customary international law.

Reference is made to the international human rights instruments such as the Convention Against Torture ('CAT'), which is interpreted as contemplating only liability of individuals ${ }^{56}$. International human rights treaties are generally viewed as imposing obligations on nations to protect the rights of individuals, but not on corporations ${ }^{57}$.

Some Briefs in support of the defendant also refer to the statute of international criminal courts pointing to the limitation of the jurisdiction of the international criminal tribunals from post-war Nuremberg to the International Criminal Court ('ICC') ${ }^{58}$ to natural persons. It is also argued that the trials conducted at Nuremberg by the International Military Tribunal ('IMT') did not charge any corporation with human rights violations. ${ }^{59}$ Scheffer, in contrast, discounts the exclusion of corporations from the court's jurisdiction as resulting from the concern of complementarity, the fact that ICC jurisdiction should mirror that of domestic tribunals, since the ICC was created as a fallback option, and, finally, the fact that, at the time of enacting the Rome Statute in 1998, many nations had not acknowledged corporate criminal liability. ${ }^{60}$

In Kiobel, the distinction made in the jurisdiction of international criminal tribunals between individuals and corporations plays a central role to assess corporate liability as a norm of customary international law. It is clear that there is a subtle connection between the two notions, but one might wonder to what extent the fact that corporations cannot be held liable under

\footnotetext{
${ }^{55}$ Kiobel (n 4) 20-28.

${ }^{56}$ UNGA 'Convention against Torture and Other Cruel, Inhuman or Degrading Treatment or Punishment' resolution adopted by the General Assembly (10 December 2004) UN Doc A/RES/39/46, Art 6.

${ }^{57}$ Chevron Amicus Brief in support of Respondents, 3 February 2012, 18.

${ }^{58}$ See Rome Statute Art 25(1), July 17, 1998, 2187 U.N.T.S. 90; International Criminal Tribunal for the Former Yugoslavia (ICTFY) Art 6, U.N. Doc. S/RES/827 (1993) as amended by U.N. Doc. S/RES/1166 (1998).

${ }^{59}$ Nuremberg Historians Amicus Brief in support of neither party, 21 December 2011, 78.

${ }^{60}$ Ambassador D. Scheffer Amicus Brief in support of the petitioners, 20 December 2011, 12-16.
} 
the ICC means that the underlying norm (i.e. genocide or crime against humanity) does not apply to these entities. While the limitations imposed on international criminal tribunals to prosecute natural rather than legal persons highlights the highly controversial debate about introducing criminal liability for corporations, it might be stretching the reasoning slightly too far to conclude that legal persons are immune from liability at national law for violating the norms in question.

\section{(c) Whether the exercise of universal jurisdiction in civil matters is conform with international law}

The extraterritoriality controversy in Kiobel illustrates the legal debate over when the protection of human rights justifies extraterritoriality. The briefs in support of the plaintiffs largely embrace the principle of universal jurisdiction, on the basis that federal courts should exercise jurisdiction over private actors who have allegedly committed serious human rights abuses, regardless of the nationality of the perpetrator or whether the harm occurred in or outside the US. The debate however, demonstrates how unclear it is whether the principle actually extends to juridical persons. The case is also representative of the tension between the classical international law tenet of non-intervention in other states' internal affairs and the values generally promoted by the entire human rights regime.

A central controversy in Kiobel relates to the "exercise of universal civil jurisdiction over alleged extraterritorial abuses to which the nation has no connection". ${ }^{61}$ After all, Kiobel concerns a claim by Nigerian citizens alleging that Royal Dutch Shell, an Anglo-Dutch multinational headquartered in The Hague aided and abetted human rights violations committed by the Abacha government in Nigeria. It is correct that the ATS constitutes a unique way of enforcing international law with no equivalent outside the US, which also explains why so many lawsuits have been brought against energy companies in the US for breach of human rights norms.

\section{(i) Extraterritoriality and international law}

The broad extraterritorial jurisdiction exercised under the ATS is described as an oddity "contrary to international law". ${ }^{62}$ Reference is made to the

\footnotetext{
${ }^{61}$ Oral Arguments (n 5) 3-4.

${ }^{62}$ Chevron Brief (n 57) 16.
} 
separate opinion in DRC v Belgium ${ }^{63}$ where three ICJ judgesrecalled the lack of international consensus concerning "[this] unilateral exercise of the function of guardian of international values". ${ }^{64}$ Shell's supporters regard universal jurisdiction as contrary to the international law principle of prescriptive jurisdiction, by which "any restriction of a nation's jurisdiction from external sources would imply a diminution of its sovereignty". 65

The imposition of civil liability is also regarded as an "intrusion" on State sovereignty by the Obama administration, which filed a supplemental amicus briefin partial support of Shell, calling for significant restrictions on the application of the ATS. ${ }^{66}$ The arguments of the US government are tied to the factual circumstances of Kiobel, but also stress the risks of international frictions, where allegations of breach of human rights involve sovereign states. The US administration observes: "although the petitioners' suit is against private corporations, adjudication of the suit would necessarily entail a determination about whether the Nigerian government has transgressed limits imposed by international law". ${ }^{67}$ Likewise, the BP brief warns against the potential for ATS suits to constitute an "unlawful infringement" ${ }^{\prime 68}$ of sovereignty. Holding Shell liable for aiding and abetting acts allegedly committed by the Nigerian government within Nigeria is thus seen as a indirect way to litigate the conduct of a foreign government that would otherwise be immune from direct suit under broader principles of state immunity. ${ }^{69}$

While the US supplemental brief has attracted criticism among supporters of human rights accountability ${ }^{70}$, blaming Western governments for resisting accusations of human rights violations, one should recall that the foreign policy concerns put forward by the US government are based on broader public and constitutional principles, which limit the authority of the judiciary to assess conflicting policy matters implicated by lawsuits. The BP brief touches on such constitutional issues, raising awareness of the

\footnotetext{
${ }^{63}$ Arrest Warrant of 11 April 2000 (Democratic Republic of the Congo v Belgium) (Judgment), 14 February 2002, [2002] I.C.J Rep, 3.

${ }^{64}$ Joint Separate Opinion of Judges Higgins, Kooijmans and Buergenthal in Arrest Warrant (n 63) [2002] I.C.J Rep 77.

${ }^{65}$ Chevron Brief (n 57) 10.

${ }^{66}$ US Government Supplemental Brief in support of partial affirmance, 13 June 2012.

${ }^{67}$ Ibid (n 66) 17.

${ }^{68}$ BP Amicus Brief in support of respondents, 3 February 2012, 16.

${ }^{69}$ ibid, 10.

${ }^{70}$ Rosario Burchielli, 'Oil for lives? When governments help bad corporations' (2012), available at http://www.latrobe.edu.au/news/articles/2012/opinion/oil-for-lives.
} 
"problem of expanding the scope of ATS liability turning federal courts into international civil courts to remedy wrong committed elsewhere". ${ }^{71}$

\section{(ii) Extraterritoriality and statutory interpretation}

In the end, whether the ATS applies to extraterritorial conduct outside the US becomes a pure exercise of statutory interpretation since the ATS is silent on the matter. A narrow interpretation consists in examining the original purpose of Congress when the statute was enacted. At that time, the objective was "to ease diplomatic frictions caused by the inadequacy of State law remedies" $" 72$ by providing "redress for violations of international law that threatened serious consequences in international affairs of the US" ${ }^{73}$ The ATS was after all enacted to provide remedies for torts committed against aliens on US soil or on the high seas, which are by essence outside territorial jurisdiction. This interpretation of the ATS is illustrated in the BP brief, which examines the wording of the statute, concluding that nothing in the terms 'alien' or 'violation of the law of the nations', suggests that Nigerian citizens can seek relief in US court for harm committed in Nigeria.

The debate on extraterritorial application of the ATS is endless. In Sarei $v$ Rio Tinto ${ }^{74}$, a case involving a similar pattern of claims to the one in Kiobel, with Papua New Guineans suing a British-Australian mining company for wrongs committed in Papua New Guinea, the Ninth Circuit's court held instead that the ATS applied to torts that occurred in foreign nations even if the alleged tort was committed by a corporation with no connection to the US. However, Judge Kleinfeld, in a dissent from the court's order, suggested that "the point of the ATS was to keep the US out of international disputes, not to inject the US into them",75, concluding: "I suspect that we lack jurisdiction because both the case involves a political question and because we lack subject matter jurisdiction on account of extraterritoriality". ${ }^{76}$

\section{(iii) Extraterritoriality and politics}

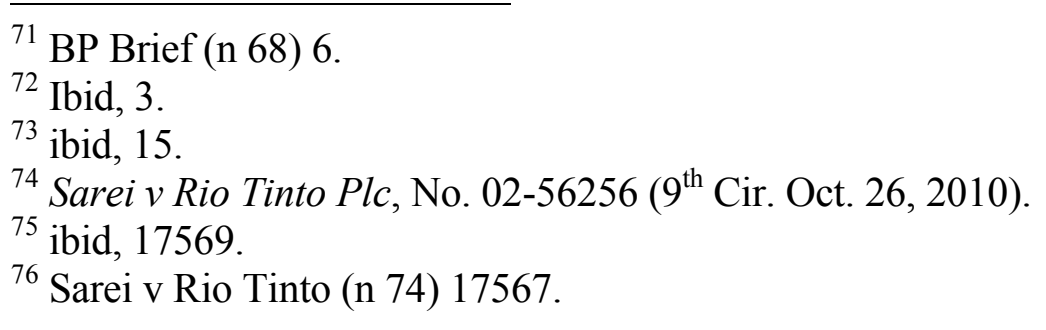


There is also a political dimension in the attempt by some governments to undermine the extraterritorial application of the ATS. ${ }^{77}$ Scholars have suggested that the involvement of the coalition of Australian Prime Minister Howard "in the Bush Administration campaign to restrict jurisdiction of the ATS" was related to the government's "general opposition to the linking of trade and investment with human rights" ${ }^{78}$ To date, Australia has not filed a brief to challenge jurisdiction in Kiobel, but one should not discount political factors influencing those who oppose the extraterritorial effects of national law in human rights litigation. The filing of briefs in support of the respondent by countries with substantial investments in oil and gas exploration worldwide, such as the UK and the Netherlands, is no coincidence. Not only would extended principles of extraterritoriality put their national industry at risk of increased litigation for human rights abuses, but they would also raise issues regarding the role of these countries in narrowing the governance gaps in countries endowed with huge oil and gas reserves.

\section{(d) Whether corporations may be found liable for violation of customary international law under aiding and abetting theory of liability and, if so, which test of complicity should apply}

Shell and its supporters finally dispute a long-standing assumption under the ATS litigation, namely, whether aiding and abetting constitutes a proper theory of liability. ${ }^{79}$ It is argued that federal law should not recognize a private right of action for aiding and abetting a foreign state's violation of human right norms. By acknowledging such a cause of action, it is feared that courts adjudicating in alleged human rights abuses by private actors might indirectly create diplomatic tensions and interfere with foreign states' domestic affairs.

The controversy then focuses on which standard of proof should apply to establish aiding and abetting liability. Shell elaborates on the high standard of the Second Circuit's earlier decision in Talisman, which held that corporations could only be found liable under aiding and abetting theory if they provided 'substantial assistance' to the primary perpetrator with the

\footnotetext{
${ }^{77}$ Anne O'Rourke and Chris Nyland, 'The Recent History of the Alien Tort Claims Act: Australia's role in its attempted downfall' (2006) 25 Australian Y.B. Int'l L., 139.

${ }^{78}$ Ibid, 140-141.

${ }^{79}$ BP Brief (n 68), 31; (n 47) Brief for Respondents (n 47), 49.
} 
'intent' (rather than mere 'knowledge') of furthering the human right violation in question.

An interesting feature of the Kiobel debate concerning whether 'knowledge' rather than 'intent' should apply to accessory corporate liability is where, and on what grounds, the parties chose to locate the legal source for establishing such standard. The fundamental divide is between sourcing the liability standard in international law $^{80}$, in line with the Talisman decision, namely in Article 25(3)(c) of the Rome Statute, or rather under domestic law, as favoured by the plaintiffs. The disagreement over the source for liability is a permanent feature of the Kiobel litigation. The starting point of corporate liability supporters is that international law defines primary violations actionable under the ATS, whilst it is federal law that determines the liability standard for complicity. On the other hand, Shell relies on Article 25(3)(c) of the Rome Statute, which provides that "...[a] person shall be criminally responsible ...for a crime within the jurisdiction of the Court...if that person ...for the purpose of [emphasis added] facilitating the commission of such crime, aids, abets or otherwise assists in its commission...", in order to infer the applicable liability standard as being one of 'intent' rather than 'knowledge'.

The purpose of this paper is not to provide an answer to such divisive debate about sourcing the norms of conduct applicable to the ATS, or the liability standard applicable to corporation that allegedly violates human rights norms, or the range of available remedies, but rather to highlight the level of complexity supporting the respective parties' views. Scheffer, who headed the US delegation in the negotiation of the Rome Statute, disputes the fact that Article 25(3)(c) reflects customary international law. He points instead to the very circumstances of the Rome Statute negotiations to recall that Article 25(3)(c) was the result of "a negotiated compromise" common law and civil law governments after years of protracted negotiations. Observing that the wording of Article 25(3)(c) was "uniquely crafted for the ICC", he concludes that only ICC judges are entitled to interpret the meaning of the 'purpose' requirement under Article 25(3)(c) ${ }^{82}$ In the meantime, and in order to determine the standard for aiding and abetting liability under the ATS, Scheffer suggests drawing upon the jurisprudence of international tribunals. In cases against the Former Yugoslav Republic and Rwanda, it was established that 'knowledge' was the

\footnotetext{
${ }^{80}$ Brief for Respondents (n 47), 52.

${ }^{81}$ Scheffer and Kaeb (n 52) 348.

${ }^{82}$ Scheffer and Kaeb (n 52) 352.
} 
only standard to prosecute individuals for aiding and abetting the commission of atrocities. ${ }^{83}$ Other scholars, like Eser, have instead favoured a narrower interpretation of Article 25(3)(c), which requires an 'intention' on the part of the aider and abettor to join the commission of the crime in question. $^{84}$

From a more pragmatic perspective, one might also argue that in the context of oil multinationals, which often operate in joint ventures with host governments, an 'intention'-based standard might ensure that their subsidiaries do not face claims solely on the basis of incidental contacts with government officials accused of violating human rights norms.

One problematic issue illustrated in Kiobel (and earlier ATS cases like Unocal, in which the court found that "the standard for aiding and abetting under the ATS" was knowledge) is the extent to which the tests establishing accomplice corporate liability are consistently derived either from the ICC Statute or the jurisprudence of other international criminal tribunals. In other words, the ATS jurisprudence including Kiobel seems to rely exclusively on the use of international criminal law to establish the parameters of corporate civil liability.

However, human rights abuses by NRCs do not necessarily require resorting to criminal remedies. Abuses arising from environmental incidents caused by oil spillage for instance, concern primarily the violation of socalled 'environmental rights'. Environmental law scholars have observed that Principle 1 of the Stockholm Declaration or international instruments such as the World Charter for Nature, provide some "justification for using criminal responsibility as a means of enforcing international environmental law". ${ }^{85}$ However, it is also possible to resort to other legal bases for establishing corporate liability. For example, negligence standards may provide such opportunities in an environmental context. Likewise, principles of agency liability ${ }^{86}$ are particularly relevant in oil exploration contexts, in which oil corporations contracting with rig drilling companies are in a position to influence operations that may lead to human rights violations.

\section{THE LESSONS FROM KIOBEL}

\footnotetext{
${ }^{83}$ Prosecutor v Anto Frundzija (Judgement) ICTY 1998 Case No. IT-95-17/1-T (10 Dec 1998), para. 245.

${ }^{84}$ Albin Eser, 'Individual Criminal Responsibility' in 'The Rome Statute of the International Criminal Court: A Commentary' (A. Cassese 2002) 767, 798-801.

${ }^{85}$ Boyle (n 24) 329.

${ }^{86}$ Clapham (n 20) 252-266.
} 
Whether the Supreme Court strikes down or severely limits the application of the ATS, the controversy in this case is significant of the limits facing US courts in adjudicating alleged corporate breach of international standards. While at the time it was enacted the ATS represented a "commitment to enforce the law of the nations ${ }^{\prime 87}$, it seems that the statute has lost part of the reach required to capture the complexity of energy multinational operations worldwide and the diverse scope of their human rights footprint.

The potential implications of a complete rejection of corporate liability under the statute raise wider issues than the extent to which international norms apply to corporations. Kiobel concerns accountability and whether it is possible to argue that, although corporations do not necessarily have obligations under international law, mechanisms under national law should be engaged to hold them accountable for wrongdoings arising from breach of international norms.

Regardless of whether the ATS is viewed as a "mechanism to enforce international law" or a mere "peculiarity" $" 88$ of the US legal system, Kiobel raises critical questions about the role of domestic legal regimes in enforcing human rights norms. If corporate liability is only a question of substantive international law obligations, as the Kiobel majority suggests, there is a risk that a gap in corporate accountability will arise. As Justice Kaganobserved, various international conventions "prohibit certain acts but do not talk about the actors". ${ }^{89}$ In such instances, where international law does not specify whether the norm in question can be violated by juridical entities, relying purely on international law might be problematic, at least from an accountability perspective.

While the Kiobel majority opposes the empowerment of domestic courts to impose liability for violation of international law as a matter of principle, this paper argues that even if some consensus was reached on this matter, the real challenge is the formulation of a coordinated approach to enforcement at national level.

\section{The Challenges of Enforcement in holding Corporations LIABLE FOR VIOLATION OF HUMAN RIGHTS NORMS}

\footnotetext{
${ }^{87} \operatorname{Sosa}(\mathrm{n} 51) 22$.

${ }^{88}$ Anthea Roberts, 'Comparative International Law? The Role of National Courts in Creating and Enforcing International Law' (2011) 60, Int'l \& Comp. L.Q. 57, 76.

${ }^{89}$ Kiobel (n 5) 27.
} 


\section{JURISDICTIONAL CHALLENGES}

\section{(a) The enforcement framework suggested by the "Guiding Principles"}

Not long before the UN Human Rights Council's endorsement of the Guiding Principles, the SRSG observed that "all national systems need to adopt a principled approach to the question of adjudicative extraterritorial jurisdiction, balancing the interests of claimant, defendant and States"..$^{90}$ This statement constitutes a strong encouragement for States in which many corporations are domiciled, to develop effective regulatory systems to address corporate liability for violation of international norms.

The Guiding Principles, per se, also provide strong support for the need for access to effective remedies by victims of human rights abuses. Guiding Principle 25 in particular requires states, "as part of their duty to protect against business-related human rights abuse [to] take appropriate steps to ensure...that when such abuses occur...those affected have access to effective remedy". 91

Whilst the Guiding Principles are not binding international law, there is some consensus that they are likely to influence national law and policy and inform domestic legal standards in jurisdictions around the world. ${ }^{92}$

\section{(b) The European Union approach to jurisdiction}

The Brussels I Regulation ${ }^{93}$ confers on courts of EU Member States the competence to adjudicate civil cases against corporations domiciled within the EU regardless of their nationality, of the place where the alleged harm occurred and of the nationality of the plaintiff. ${ }^{94}$ Domiciliation is defined by reference to the corporation's "statutory seat" or "principal place of business" ${ }^{95}$ The Regulation has been praised for its certainty ${ }^{96}$. Thus, whilst the US Supreme Court seeks, in Kiobel, to establish whether Shell, an

\footnotetext{
${ }^{90}$ UNHRC 'Report of the Special Representative on the issue of human rights and transnational corporations and other business enterprises' (April 9, 2010) UN Doc A/HRC/14/27, para 107.

${ }^{91}$ UNHRC, Seventeenth Session (n 18) 22.

${ }^{92}$ Menno Kamminga, "Ruggie has created energy, consensus and platform to build upon”, AmLaw Daily (20 December 2010).

${ }^{93}$ Council Regulation (EC) 44/2001 on jurisdiction and the recognition and enforcement of judgments in civil and commercial matters [2000] OJ L12/1.

${ }^{94}$ ibid, Art 2.1.

95 ibid, Art 60.1.

${ }^{96}$ Liesbeth F.H. Enneking 'Transnational Corporate Responsibility for the $21{ }^{\text {st }}$ Century: Crossing the Atlantic? The Political and Legal Feasibility of European Foreign Direct Liability Cases' (2009) Geo. Wash. Int'l L. Rev. 903, 916.
} 
Anglo/Dutch corporation is a proper defendant under the ATS for alleged human rights violations in Nigeria, a European court would probably hold that it is not, on the basis of Brussels I. Ennerking correctly argues that the mandatory nature ${ }^{97}$ of the European regime theoretically "precludes any decline of jurisdiction by an EU Member State court" $" 98$ on the basis of forum non conveniens. Cases can now proceed against NRC parent companies domiciled in EU members States without the obstruction of forum non conveniens disputes. ${ }^{99}$

However, the issue of forum non conveniens remains alive in common law countries outside the EU. ${ }^{100}$ There, jurisdictional issues are often more complex and, as case law demonstrates, jurisdiction often depends on how courts are prepared to interpret these rules. Based on Brussels I, the Court of The Hague in the Shell Oruma case had mandatory jurisdiction over the Netherlands-based parent, Royal Dutch Shell Plc. However, Shell contended that the Dutch court lacked jurisdiction over SPDC, the Nigerian subsidiary, disputing the use by the plaintiffs of procedural principles under Dutch law ${ }^{101}$ to enable the joinder of SPDC to the Netherlands-based parent. The defendant's central argument was that the plaintiffs had initiated claims against RDS on a "patently inadequate basis for the sole purpose of creating jurisdiction for SPDC". ${ }^{102}$ However, the Dutch Court dismissed Shell's claim, relying on a strict interpretation of Dutch civil procedure ${ }^{103}$ and concluding that the claims against the parent and the subsidiary were sufficiently connected (i.e. based on the "same complex facts in Nigeria"104) to grant jurisdiction to SPDC.

\footnotetext{
${ }^{97}$ The ECJ clarified in Case C-281/02 Owusu v Jackson and Ors [2005] QB 801 that national courts in the EU do not have power to stop proceedings against EU domiciled defendants on the basis of forum non conveniens, when the alternative forum is outside the EU.

${ }^{98}$ Enneking (n 96) 918.

${ }^{99}$ Meeran (n 11) 20.

100 Recherches Internationales Quebec v Cambior [1998] Q.J. No. 2554: Quebec Supreme Court judged dismissed proceedings against Canadian mining company observing that "neither victims nor their action has any connection with Quebec".

101 Dutch Code of Civil Procedure Article 7, available at http://www.dutchcivillaw.com/civilprocedureleg.htm.

${ }^{102}$ Shell (n 21) para. 2.4.

${ }^{103}$ Ibid, para. 3.4.

${ }^{104}$ Ibid, para. 3.6.
} 


\section{(c) National law obstacles to extend jurisdiction}

While the Brussels I framework points to some consensus around extraterritorial jurisdiction, provided that a nexus exists between the home state's forum and the corporation accused of a human rights violation, initiatives to promulgate national laws that extend the extraterritorial reach of domestic courts remain limited. The initiative to extend the authority of Canadian Federal Courts to protect foreigners against a broad range of human rights violations, including environmental degradation and transboundary pollution by Canadian-based multinationals raised the expectations of corporate liability advocates. ${ }^{105}$ So far, however, the socalled "Bill on CSR"106 presented to the Canadian Parliament in April 2009, has not been adopted.

\section{SUbSTANTIVE ChaLLENGES}

There are at least three substantive challenges in terms of domestic enforcement in the context of corporate liability.

\section{(a) Establishing private rights of action}

Decisions to create private rights of action are generally questions left to the legislature. In the US, for instance, civil liability for torture is implemented in the Torture Victim Protection Act ('TVPA') ${ }^{107}$, which establishes a cause of action for victims of torture or extraterritorial killings. ${ }^{108}$

The wording of Article 2(a) TVPA, which refers to the liability of "individuals" has left some controversy as to whether the TVPA applies to corporations, although Joseph observes that courts have interpreted the term 'individual' as "encompassing [...] corporations". 109

\section{(b) Deducing corporate obligations from human rights norms}

The South African Constitution is remarkable in specifying that its Bill of Rights binds corporations as well as natural persons. ${ }^{110}$ Even if the

\footnotetext{
${ }^{105}$ Scheffer and Kaeb (n 52) 372.

${ }^{106}$ Bill C-354 ('An Act to amend the Federal Courts Acts') House of Commons of Canada (Apr, 1 2009) at http://openparliament.ca/bills/40-3/C-354/.

10728 USC \& 1350 pursuant to Art 14(1) CAT.

${ }^{108}$ Ibid, Art 2(a).

${ }^{109}$ Joseph (n 36) 61-63.

${ }^{110}$ Constitution of the Republic of South Africa Chapter 2, promulgated 18 December 1996, s. 8(2), available at http://www.info.gov.za/documents/constitution/1996/a10896.pdf.
} 
obligation is further qualified by the "nature of the right" and "the nature of the duty imposed by the right", unlike other countries where the application of the norms is not specified, the South African Constitution provides a secure ground for corporate liability for breach of human rights norms. Although some countries have passed legislation to affirm rights that are relevant in the debate on corporate liability (e.g. recent Peruvian law that guarantees indigenous peoples rights to free prior and informed consent to projects affecting their land ${ }^{111}$ ), it is not clear whether the South African model constitution, in clarifying who bears human rights obligations, has been adopted elsewhere.

\section{(c) Determining liability principles}

There is a deeply entrenched doctrine in corporate law that a corporation's subsidiary is a body distinct from its parent company. Aimed to induce shareholders to invest, the doctrine has its foundations on the principle of 'limited liability'. This principle suggests that a parent company cannot be held liable for the acts of its subsidiary, which is a separate legal entity, subject to the laws of the host country ('corporate veil'). In the Shell Oruma case, for instance, Shell relied on the 'corporate veil' in its defense. ${ }^{112}$ By contrast, the plaintiffs, relying on the Cape case as legal authority ${ }^{113}$, alleged that the Shell parent had breached its duty of care to the Nigerian farmers, since the parent had not "exercised its influence on and control over the subsidiary's environmental policy to avoid the harm". ${ }^{114}$

So far, at least in the UK, the 'corporate veil' doctrine remains anchored in the laws and there is no sign that the legislature will question this on human rights grounds. Whether a UK-based parent company can be held liable for the acts of its subsidiary remains in the hands of the judiciary. There are limited circumstances under which the 'corporate veil' will be pierced under English law. The courts have developed a concept of duty of care, whereby a parent company may incur liability where it owes a duty of care to the claimant. ${ }^{115}$ In the Lubbe $v$ Cape case, the Court of Appeal asked

\footnotetext{
111 "Prior Consultation Law", available at http://www.ipsnews.net/2010/05/peru-nativepeoples-right-to-consultation-on-land-use-enshrined-in-law/.

${ }^{112}$ Motion for the Court to Decline Jurisdiction and Transfer the Case, Docket number 2009/0579, http://www.milieudefensie.nl/publicaties/bezwaren-uitspraken/shellsresponse-to-the-subpoenas 13 May 2009, 45-53.

${ }^{113}$ Lubbe \& Ors $v$ Cape Plc [2000] UKHL 41, [2000] WLR 1545, 6.

114 Judgment in motion contesting jurisdiction of 30 December 2009 (n 21) para 2.2.

${ }^{115}$ Lubbe\&Ors v Cape Plc [1998] CLC 1559.
} 
whether such duty existed where the parent exercised de facto control over the operations of the subsidiary and knew, through its directors, that those operations involved risks to the health of the workers employed by that subsidiary. Comments by Lord Bingham in the House of Lords judgment ${ }^{116}$ suggest that, for a parent company to breach its duty of care, the parent must have failed to take action to reduce the risks associated with the subsidiary's operations. In those circumstances, this meant a failure to ensure the observance of proper health and safety standards. More recently, the Court of Appeal's decision in Chandler $v$ Cape PLC ${ }^{117}$ is probably more significant, as it set specific parameters to deduce the liability of the parent company. The case involved a claim for asbestosis contracted as a consequence of poor working conditions in South Africa and the court allowed a case to be brought against the parent company in the UK.

\section{IS CORPORATE CRIMINAL LIABILITY THE WAY FORWARD?}

\section{(a) The implementation of international crimes into national legislation}

As highlighted by the Norwegian multidisciplinary research foundation FAFO in a surveyconducted in sixteen jurisdictions, an increasing number of countries have incorporated the three crimes defined under the Rome Statute, namely crime against humanity, genocide and war crimes, into their domestic law. ${ }^{118}$ Also significant is the elimination of the jurisdictional limitation placed by Article 25(1) of the Rome Statute through domestic law. The survey observes that most countries no longer distinguish between natural and juridical persons in incorporating international crimes into domestic law.

Some countries have been strong supporters of corporate criminal liability. France, for instance, allowed corporations to be prosecuted for legal offences as early as 1994, introducing criminal sanctions and fines ranging from dissolution of the corporation to confiscation of corporate assets. ${ }^{19}$ There are recognized advantages in holding corporations liable for criminal acts: enforcement measures and penalties are often more stringent than civil remedies and the stigma associated with criminal sanctions is regarded as having a more effective deterrent effect on future corporate wrongdoings.

\footnotetext{
${ }^{116}$ Lubbe (n 113).

${ }^{117}$ David Brian Chandler v Cape Plc [2012] EWCA Civ 525.

${ }^{118}$ Anita Ramasastry and Robert Thompson 'Commerce, Crime and Conflict: Legal Remedies for Private Sector Liability for Grave Breaches of International law' (2006), 15. ${ }^{119}$ French Criminal Code ('Code Penal'), Arts 131-137.
} 
However, there are also important limitations and it is arguable that, as the current law stands, the scope for prosecution of NRCs for criminal acts, remains limited. Save for strict liability offences, proving the mental element of a crime for legal entities is required. One method of establishing the intention or recklessness of a legal entity is to use the identification principle', which requires attributing the intent of a crime to the 'directing mind' of the corporation (i.e. the directors or the senior management). ${ }^{120}$ More liberal approaches require that a 'corporate culture' exists "within the body corporate" ${ }^{121}$ in question, with 'corporate culture' being defined in broad terms as "an attitude, policy, rule, course of conduct". ${ }^{122}$ In any case, the attribution of intent is not obvious. There are also specific enforcement difficulties that make the conviction of corporations for violation of human rights norms technically impossible. For instance, under English law, while torture, genocide and crimes against humanity are criminal offences ${ }^{123}$, these crimes are only subject to custodial punishment. ${ }^{124}$ Since corporations cannot be found liable for offences punishable by imprisonment ${ }^{125}$, it follows that corporations cannot be convicted for violation of these specific human rights norms.

Unsurprisingly, the Trafigura case did not result in any corporate criminal prosecution in the UK Courts. Instead, Ivorian plaintiffs brought a civil suit in the London High Court seeking compensation for the physical harm and property damages caused by the 'Probo Koala' incident. Criminal liability was only established for a limited number of individuals involved with the incident. Whilst the 'Probo Koala' captain and the Trafigura officer responsible for the discharge of the slops received suspended prison sentences, respectively of five and six months in Dutch courts ${ }^{126}$, the most serious sentence - 20-year imprisonment - was imposed by an Abidjan court on the owner of the company contracted for the disposal of the waste. Ironically, Trafigura's main shareholder and founder remained insulated from criminal prosecution for leading the export of the waste to the Ivory Coast.

\footnotetext{
${ }^{120}$ Oxford Pro Bono Publico: 'Obstacles to Justice and Redress for Victims of Corporate Human Rights Abuse', University of Oxford (3 November 2008) 266.

${ }^{121}$ Australia Criminal Code Act 1994, s. 12.3(2)(c).

122 ibid, s. 12.3(6).

${ }^{123}$ International Criminal Courts Act 2001 s 51-52.

124 ibid, s. 53.

${ }^{125}$ Halsbury's Corporations' Laws of England (2006), para. 1280.

${ }^{126}$ District Court, Amsterdam, 23 July 2010, Case No 13/994066.
} 


\section{(b) Ecocide and the question of individual criminal liability}

The Trafigura case demonstrates the limitations of the current criminal legal regime to hold corporations accountable for violating human rights norms. The incorporation through domestic law of international crimes has so far been concentrated on the four "crimes against peace", namely Genocide, Crimes Against Humanity, War Crimes and Crimes of Aggression. ${ }^{127}$ At the international level, recent proposals to introduce 'ecocide' as a fifth crime against peace to address large scale destructions of ecosystems, including corporate activities associated with the depletion of natural resources, might be a way forward. ${ }^{128}$ The principle of complementarity under the Rome Statute would, in turn, exercise pressure on States to implement ecocide as a crime at national level. This possibility was ventilated in the mock ecocide trial held in London in September 2011. ${ }^{129}$ However, the effectiveness of ecocide will depend on domestic enforcement. Corporations are fictional entities with decisions made by directors and senior management. If the purpose of corporate liability is to deter corporations from violating international norms, it is suggested that these individuals should be held liable individually. Whether liability should be directed at corporations or individuals raises the difficult question of responsibility allocation. The approach of the Australian Criminal Code, which relies on 'corporate culture', can be praised for its flexibility but, at the same time, the Nuremberg tribunals (arguably at the very heart of crimes against humanity) demonstrated that 'systems', only constitute the means by which individuals engage in criminal activities and therefore cannot provide the sole reason for attributing responsibility.

\section{E. CONCLUSION}

As Kiobel demonstrates, whether a principle of corporate liability for violation of human rights norms has materialized at international law remains largely unanswered. Whether the difficulty to find sources of international law that hold corporations liable for human rights abuses

\footnotetext{
${ }^{127}$ United Nations, 'Final Act of the UN Diplomatic Conference of Plenipotentiaries on the Establishment of an International Criminal Court' (17 July 1998) UN Doc A/CONF. 183/10, Art. 5.

${ }^{128}$ Poli Higgins, Eradicating Ecocide (Shepheard-Walwyn 2010), 61-71.

129 The Hamilton Group, 'The Ecocide Trial: The Supreme Court of the United Kingdom', $\quad 30 \quad$ September 2011, available at http://www.thehamiltongroup.org.uk/common/ecocide.asp.
} 
justifies corporate impunity is another question. A complete rejection of corporate liability based on the indeterminacy of international standards defies common sense. The incorporation of charges for international crimes into domestic law following the ratification of the Rome Statute demonstrates the capacity of national legal systems to hold corporations accountable. However, relying on domestic law to determine the pathways for corporate accountability is not without challenge.

Public consensus is pushing for more international supervision in standard setting. Proposals range from international conventions on safety standards for oil platforms ${ }^{130}$ to treaties embracing broader corporate human rights obligations. ${ }^{131}$ Such conventions are believed to help host governments resist the pressure of the oil industry to reduce regulatory supervision. These proposals however, overlook two problems. First, home states are not necessarily willing to expand principles of corporate accountability, as is evidenced by the current opposition of the US government in Kiobel to extend jurisdiction for corporate harms committed outside the US, or the caution of the Canadian Parliament to enact Bill C354.

Secondly, host states can be torn between the steps required to "strengthen domestic social and environmental standards" 132 and to "ensure the effectiveness of judicial mechanisms" ${ }^{\prime 13}$ on the one hand, and the threat of arbitration for violating guarantees under BITs on the other hand. There is a significant risk faced by host states to entertain litigation against large oil companies. Effectively, the host state may find itself conflicted between its duty to grant access to domestic judicial mechanisms and the risk that the oil company will later invoke the violation of a BIT between the host state and the state of the investor, arguing that the course of justice has been perverted in the domestic courts. The arbitration faced by Ecuador for allegedly failing to provide due process, whilst an Ecuadorian court issued a multi-billion

\footnotetext{
${ }^{130}$ James Harrison, 'The Gulf of Mexico Oil Spill and International Law', IL Observer (31 May 2010).

${ }^{131}$ Joint Civil Society Statement at $17^{\text {th }}$ Session of the Human Rights Council, Human Rights Watch, 30 May 2011, available at http://www.hrw.org/news/2011/05/30/jointcivil-society-statement-17th-session-human-rights-council.

${ }^{132}$ UNHRC, Eighth Session (n 12) para 34.

${ }^{133}$ UNHRC, Seventeenth Session (n 18) Guiding Principle 26, 23.
} 
verdict demanding Chevron in February 2011, to fund environmental remediation for oil pollution, is an example of this sort of conflict. ${ }^{134}$

Growing concern regarding corporate impunity might generate further reform: mechanisms could be introduced into BITs to correct the "imbalance between investors' rights and the State duty to protect human rights"135, ecocide might be adopted as a fifth crime against peace to address environmental degradation caused by NRCs, requirements for piercing the 'corporate veil' could be harmonized across jurisdictions. However, reform is a complex and multi-faceted process. While the Human Rights Council has been urged to "establish a robust follow-on mechanism to build on the SRSG efforts" $" 136$, success might ultimately depend on the willingness of national legal systems to promote accountability mechanisms as a policy option.

${ }^{134}$ Chevron Corporation and Texaco Petroleum Company v The Republic of Ecuador (PCA Case No 2009-23), available at http://www.pcacpa.org/showpage.asp?pag_id=1408.

${ }^{135}$ UNHRC Eleventh Session 'Report of the Special Representative of the SecretaryGeneral on the issue of human rights and transnational corporations and other business enterprises, Business and human rights: Towards operationalizing the "protect, respect and remedy" framework' (22 April 2009) UN Doc A/HRC/11/13, para 30.

${ }^{136}$ Joint Civil Society Statement (n 131). 